\title{
0 ponto em que estamos na historiografia sobre o período de rompimento entre Brasil e Portugal.
}

The current stage of historical studies concerning the Brazilian independence from Portugal

\section{Lucília Siqueira}

Professora da Pontificia Universidade Católica de São Paulo

\begin{abstract}
Resumo
Nos últimos anos, pareceu que o debate historiográfico sobre o final do período colonial ficaria reduzido à questão da oposição ou coincidência de interesses entre a colônia e a metrópole. Este artigo busca mostrar que vários historiadores da atualidade já ultrapassaram a dita dicotomia ao escreverem a história da separação entre Brasil e Portugal numa perspectiva "culturalista" e levando em conta as múltiplas temporalidades existentes na realidade passada que estudam. Pretendemos fazê-lo por meio da análise do livro Independência: história e historiografia, organizado pelo professor István Jancsó e lançado no segundo semestre de 2005 pela Hucitec e pela Fapesp.
\end{abstract}

\begin{abstract}
Lately, historiographical debates about the last decades of the colonial period seemed reduced to the issue of either a confrontation or an agreement of interests between Colony and Metropole. This article attempts to demonstrate that many among contemporary historians have already overcome this alleged dichotomy, in favor of a more culturally contextualized approach of the separation of the two countries, which takes into account different temporalities coeval to the complex reality of the period. It is our present intention to make such demonstration through an analysis of the book "Independence: History and Historiography", organized by István Jancsó and released during the last semester of 2005 by Hucitec and FAPESP.
\end{abstract}

\section{Palavras-chave}

historiografia, Independência, história política

\section{Keywords}

historiography, Independence, political history 
Caio Prado Júnior. Formação do Brasil

Contemporâneo. Colônia. São Paulo: Brasiliense, 1965. A primeira edição do livro é de 1942.

2

Idem, p.341-ss. Ver também Maria Odila Leite da Silva Dias. "Impasses do inorgânico" In: Maria Ângela D'Incao. História e ideal. Ensaios sobre Caio Prado Jr. São Paulo: Brasiliense/UNESP/ Secretaria da Cultura, 1989, p. 377-405.

3

István Jancsó (org.). Independência: história e historiografia. São Paulo: Hucitec/Fapesp, 2005 $934 \mathrm{p}$.

István Jancsó. "Independência, independências" In: István Jancsó (org.). Independência: história e historiografia. São Paulo: Hucitec/Fapesp, 2005, p. $17-48$

5

Principalmente: Manuel de Oliveira Lima. D.João VI no Brasil: 1808-1821. Rio de Janeiro : Typ. do Jornal do commercio, 1908.

6

Caio Prado Jr. Evolução política do Brasil. São Paulo: Revista dos Tribunais, 1933, e Caio Prado Jr. Formação do Brasil Contemporâneo. São Paulo: Martins, 1942

7

Fernando Novais. Portugal e Brasil na crise do antigo sistema colonial (1777-1808). São Paulo: Hucitec, 1989. Resultado de sua tese de doutoramento no início da década de 1970.

\section{8}

José Honório Rodrigues. Independência: revolução e contra-revolução. São Paulo: Francisco Alves, 1975. Obra lançada no bojo do Sesquicentenário de 1972.

9

Carlos Guilherme Mota (org.). 1822: Dimensões. São Paulo: Perspectiva, 1986. Coletânea de vários autores publicada originalmente na ocasião do Sesquicentenário de 1972.

\section{0}

István Jancsó. "A sedução da liberdade" In: Fernando Novais (dir.) História da vida privada no Brasil. São Paulo: Companhia das Letras, 1997, vol.1, p. 388-477.

11

Maria Odila Leite da Silva Dias. "A interiorização da metrópole (1808-1853)" In: A interiorização da metrópole e outros estudos. São Paulo: Alameda, 2005. p.7-37. Originalmente publicado em Carlos Guilherme Mota (org.). 1822: Dimensões. São Paulo: Perspectiva, p.160-184.

\section{2}

IImar Rohloff de Mattos. O tempo saquarema A formação do Estado Imperial. Rio de Janeiro: Access, 1999. Resultado de sua tese de doutoramento defendida em 1985.

13

Alcir Lenharo. As tropas da moderação. 0 abastecimento da Corte na formação política do Brasil, 1808-1842. São Paulo: Símbolo, 1979.
Desde o "Sentido da Colonização" de Caio Prado Júnior, ${ }_{1}^{1}$ portanto desde os meados do século XX, consolidou-se entre nós uma perspectiva historiográfica que entendia como antagônicas as relações entre o Brasil colonial e o Portugal metropolitano. Embora este autor tenha distinguido do Estado a natureza e as origens da nação brasileira, indicando que esta surgiria da porção "inôrganica" da sociedade colonial, isto é, daquilo que escapou à colonização e que não se encontrava nas grandes propriedades que produziam para o mercado externo com mão-de-obra escrava africana ${ }_{1}{ }^{2}$ ainda assim floresceu entre nós desde então uma historiografia da Independência cuja criticidade apostava na permanência das estruturas coloniais.

$\mathrm{Na}$ última década, contudo, assistimos o aparecimento de muitas obras historiográficas que vêem a América portuguesa mais como parte do Império lusitano do que como colônia, ou seja, que realçam as coincidências culturais, políticas e econômicas entre as partes dos dois lados do Atlântico. Durante alguns poucos anos, pareceu que o debate historiográfico sobre 0 final do período colonial ficaria reduzido à questão da oposição ou coincidência de interesses entre a colônia e a metrópole.

Este artigo busca mostrar que vários historiadores da atualidade já ultrapassaram a dita dicotomia ao escreverem a história da separação entre Brasil e Portugal, construindo-a numa perspectiva "culturalista" e levando em conta as múltiplas temporalidades existentes na realidade passada que estudam. Pretendemos fazê-lo por meio da análise do livro Independência: história e historiografia, lançado no segundo semestre de 2005 pela Hucitec e pela Fapesp. ${ }^{3}$ Resultado do Seminário Internacional "Independência do Brasil: História e Historiografia", realizado na Universidade de São Paulo em setembro de 2003, este livro de 934 páginas e 27 historiadores, com sua dimensão e variedade de autores, colocou em novo patamar a discussão sobre nosso passado colonial.

0 livro inicia com o texto "Independência, independências"4 do professor István Jancsó, que igualmente organizou o Seminário e o volume, e é o coordenador geral do Projeto Temático "A Formação do Estado e da Nação Brasileiros (1750-1850)", do qual participam alguns dos pesquisadores presentes neste livro. Após este primeiro texto, o Independência: história e historiografia está montado em cinco partes: Historiografia da Independência, Independência e abrangências imperiais, A Independência nas partes do Brasil, Instrumentos da política e, finalmente, Idéias e interesses. Aqui não tratamos de todos os artigos, evidentemente; examinamos apenas aqueles que nos pareceram mais representativos no conteúdo propriamente, seja na abordagem, na interpretação ou no objeto escolhido, e também os que tocam mais diretamente em algumas das questões historiográficas e teóricas que julgamos relevantes para o debate em torno da crise do Antigo Regime no Império português, da crise nas relações coloniais.

Em se tratando de temática tão estudada, quase a totalidade dos autores do Independência discute com a produção que Ihes é anterior, tornando-nos possivel rever, por seus olhos de hoje, estudos sobre o fim do período colonial desde Oliveira Lima ${ }^{5}$, Caio Prado Júnior 6 , Fernando Novais ${ }^{7}$, José Honório Rodrigues ${ }^{8}$, Carlos Guilherme Mota ${ }^{9}$, István Jancsó10 e Maria Odila Leite da Silva Dias ${ }^{11}$, passando por IImar Mattos ${ }^{12}$, Alcir Lenharo13, Fernando Novais em "Condições de privacidade..."14, Maria de Lourdes Vianna Lyra ${ }^{15}$, lara Lis Carvalho Souza ${ }^{16}$, o Antigo Regime nos trópicos, de 
Fernando Novais. "Condições da privacidade na colônia" In: Laura de Mello e Souza (org.). História da vida privada no Brasil. São Paulo: Companhia das Letras, 1997, vol.1, p. 13-39.

\section{5}

Maria de Lourdes Vianna Lyra. A utopia do poderoso império. Portugal e Brasil: bastidores da política, 1798-1822. Rio de Janeiro: 7 Letras, 1994.

\section{6}

lara Lis Carvalho Souza. Pátria coroada. O Brasil como corpo político autônomo (1780-1831). São Paulo: Unesp, 1999.

17

João Fragoso, Maria Fernanda Bicalho e Maria de Fátima Gouvêa (org.). O Antigo Regime nos trópicos. A dinâmica imperial portuguesa (séculos XVI-XVIII). Rio de Janeiro: Civilização Brasileira, 2001.

\section{8}

István Jancsó e João Paulo Pimenta."Peças de um mosaico (ou apontamentos para o estudo da emergência da identidade nacional brasileira)" In: Carlos Guilherme Mota (org.). Viagem incompleta. A experiência brasileira (15002000). São Paulo: Senac, 2000, p. 127-175.

19

Benedict Anderson. Nação e consciência nacional. São Paulo: Ática, 1989.

\section{0}

Manuel Valentim Alexandre. Os sentidos do Império. Questão nacional e questão colonial na crise do Antigo Regime português. Porto: Afrontamento, 1992.

21

Roderick Barman. Brazil. The Forging of a Nation, 1798-1852. Stanford: Stanford University Press, 1988.

22

François-Xavier Guerra. "A nação na América espanhola. A questão das origens". Revista Maracanan. Rio de Janeiro, n.1, 1999/2000, p.9-30.
João Fragoso e outros 17 , István Jancsó e João Paulo Pimenta em "Peças de um mosaico (ou apontamentos para o estudo da emergência da identidade nacional brasileira)"18. Entre os estrangeiros, os mais citados são Benedict Anderson ${ }^{19}$, Manuel Valentim Alexandre ${ }^{20}$, Roderick Barman ${ }^{21}$ e FrançoisXavier Guerra22, nesta ordem de recorrência. É verdade ainda que, mesmo apresentando pesquisas recentes, os autores citam-se bastante entre si, esclarecendo-se mutuamente e mostrando que, de fato, constituem um grupo, com uns mais próximos e outros um pouco mais desgarrados, onde partilham leituras e, principalmente, movem-se pelas mesmas perguntas, 0 que acaba por aplainar qualquer grande desigualdade entre os artigos. Este livro é, desde já, uma peça essencial na história da historiografia brasileira, pois desvela e documenta o ambiente acadêmico em que se constrói a história do Brasil na atualidade: nas notas estão as referências mais significativas, os autores mais lidos, os mais inspiradores e os mais detraídos do momento, os arquivos onde se vasculha e os documentos analisados; depois de ler alguns artigos do Independência: história e historiografia, podemos saber como caminha a produção do conhecimento histórico no país. Pelo que se vê, vai muito bem.

\section{0 geral e o específico nas experiências políticas na época da Inde- pendência}

A crise do Antigo Regime reverberou nas muitas partes do Império lusitano e gradualmente foi acentuando fissuras entre classes dominantes ultramarinas. Além do aspecto político, aquelas décadas do final do Setecentos e início do Oitocentos assistiram mudanças importantes no campo econômico, como o desenvolvimento das capitanias do Norte da América portuguesa, impulsionadas pelas medidas que o governo português thes reservava desde os tempos de Pombal, e como a decadência da atividade mineradora e os rearranjos agrários e mercantis que dela surgiram. Em muitos cantos desta América expandiram-se as vias de comunicação, aumentou o volume de mercadorias transacionadas - fosse entre as capitanias, para cruzar o Atlântico ou as fronteiras do Sul - e cresceu o número de unidades administrativas locais, sem falar na explosão demográfica. Tudo isso, aliado à mudança da sede do governo imperial para o Rio de Janeiro e, anos depois, à explosão da revolução liberal no Porto, terminou por formar um quadro movediço que instava os potentados locais e regionais a novos embates e reacomodações, entre si e em relação à população dos escravos e da gente livre e pobre.

Em cada região, os conflitos tomaram coloração e força variadas, dependendo da natureza dos liames mais e menos estreitos que se tinha com Lisboa - nos negócios e nos aparatos de governo -, da dimensão e da resistência da escravaria e dos forros no conjunto da população, da intensidade da pressão exercida pelos pobres que nasceram livres, do grau de militarização, do nível de disseminação das idéias ilustradas e da maneira como eram assimiladas e, ainda, do entrosamento que os mais abastados tinham ou não com a Corte do Rio de Janeiro. A situação criada pelo movimento liberal português expôs muito mais as diferenças de pensamento e intensificou a luta política no Reino americano; isso se fez, nas diferentes províncias, por facções ancoradas em um conjunto de motivações distintas mas bastante pegadas, as quais cabe ao historiador distinguir. Houve os que lutavam para alcançar posições na nova ordem institucional, os que lutavam porque estavam convencidos do valor da Constituição, houve os 


\section{3}

Matthias Röhrig Assunção. "Miguel Bruce e os 'horrores da anarquia' no Maranhão, 1822-1827" In: István Jancsó (org.). Independência: história e historiografia, p. 345-378.

André Roberto de A. Machado. "As esquadras imaginárias. No extremo norte, episódios do longo processo de Independência do Brasil" In: István Jancsó (org.). Independência, op. Cit., p. 303-343.
25

Idem, p. 343 que defendiam a manutenção da ordem institucional e ainda outras variações dessas tendências. 0 desenrolar deste instável quadro político-institucional ultrapassou a proclamação do Príncipe e até as adesões mais tardias de algumas províncias, como mostram os estudos recentes sobre Pernambuco, Maranhão, Pará e Bahia, onde as comoções persistiram. Vejamos, então, as especificidades regionais do processo de Independência conforme apresentadas nesta coletânea.

Na província maranhense, a união com o governo de D.Pedro foi forçada pela invasão das tropas independentistas que vieram do Piauí e do Ceará e foi oficializada no final de julho de 1823. No entanto, segundo Matthias Röhrig Assunção em "Miguel Bruce e os 'horrores da anarquia' no Maranhão, 1822-1827", 23 a independência promovida no Maranhão excedia aquela empreendida pelo Rio de Janeiro, já que o presidente Bruce, primeiro a assumir depois da adesão ao Príncipe, não conseguiu restabelecer a ordem, tendo agido contra os portugueses e sido acusado de estimular as revoltas das gentes de cor, bem como de se filiar aos revoltosos da Confederação do Equador.

Quanto ao Pará, uniu-se ao governo de D.Pedro em agosto de 1823. Conforme André Roberto de A. Machado, ${ }^{24}$ as divergências existentes entre os paraenses também iam além da Independência. Para o pesquisador, uma unidade administrativa distinta da do Estado do Brasil durante boa parte do período colonial, criando uma relação política e administrativa sempre mais próxima de Lisboa; as relações comerciais muito fortes entre os negociantes do Pará e os do Reino de Portugal; a existência de um bloco regional de interesses comuns em torno da província paraense, composto por Maranhão, Piauí, Goiás e Mato Grosso; e, ainda, a presença significativa da mão-de-obra indígena na economia provincial e a importância variada da mão-de-obra escrava africana entre as regiões do Pará; tudo isso fazia daquela área uma especificidade no conjunto da América portuguesa. Do ponto de vista político, as divisões entre as elites eram tão acentuadas que impossibilitavam a criação de uma força hegemônica que garantisse a ordem e alguma estabilidade; daí ser tão importante a ajuda militar externa, tantas vezes imaginada e falsamente anunciada, fosse oriunda dos aliados maranhenses, das esquadras portuguesas - como muitas vezes as autoridades paraenses solicitaram a Lisboa - ou das forças a serviço do novo "Sistema do Rio de Janeiro".

Neste cenário são narrados os acontecimentos paraenses de 1821, 1822 e 1823, nos quais protagonizou em posição conservadora o governador de armas José Maria de Moura. Outros grupos, de tendência liberal, também lutavam para manter os laços de união política com Lisboa, mas faziam-no contra o tal Moura e em cooperação com as autoridades do Mato Grosso, Maranhão e Goiás. Num determinado momento, a situação acabou sendo decidida pela

"(...) impossibilidade de se manter um bloco de províncias unidas a Portugal" e pela "crença de que com o apoio das forças imperiais, o partido que estivesse alinhado ao Rio de Janeiro conseguiria assegurar a ordem interna, algo que então nenhum grupo da província podia fazer."25

No entanto, os contemporâneos entenderam que a adesão ao Império brasileiro não era definitiva, como ficou demonstrado pela continuidade das lutas políticas depois de agosto de 1823 e como o pesquisador já adiantava desde o título de seu texto. 
Denis Antonio Bernardes. "Pernambuco e sua área de influência: um território em transformação (1780-1824)" In: István Jancsó (org.). Independência, op. Cit., p. 379-409.
27

István Jancsó e João Paulo Pimenta. "Peças de um mosaico (ou apontamentos para o estudo da emergência da identidade nacional brasileira)" In: Carlos Guilherme Mota (org.). Viagem incompleta. A experiência brasileira (15002000). São Paulo: Senac, 2000, p. 138.
28

Helga Iracema Landgraf Piccolo. "0 processo de independência numa região fronteiriça: o Rio Grande de São Pedro entre duas formações históricas" In: István Jancsó (org.). Independência, op. Cit., p. 577-613.
André Machado, da Universidade de São Paulo, encerra seu "As esquadras imaginárias. No Extremo Norte, episódios do longo processo de Independência do Brasil" chamando a atenção para o deslize que se cometeu com a história do Pará no processo de Independência, pois, entendendo-a como uma história muito específica, alguns pesquisadores restringiram sua análise aos limites territoriais da província, deixando de apreender o "bloco regional" que por ele é examinado. Em relação à historiografia que se mantinha presa à configuração político-administrativa, oficial, é um avanço tomar como campo de estudo a região em que os homens do passado construíram suas alianças políticas, militares e familiares, realizavam suas trocas comerciais e, também, disputavam o domínio sobre os demais grupos sociais.

Denis Antonio Bernardes propõe o mesmo no seu texto sobre "Pernambuco e sua área de influência", 26 que ia das Alagoas ao Ceará, onde, ao longo da segunda metade do XVIII e o início do XIX, houve crescimento demográfico nas áreas rurais e urbanas, desenvolvimento da lavoura de algodão e aumento do número de pequenos e médios proprietários que faziam uso de mão-de-obra livre, o que foi reconhecido pelo Estado português com um reordenamento administrativo e judicial, na forma de novas vilas e comarcas. 0 tratamento do historiador pernambucano para as cinco capitanias em conjunto é referendado por uma citação do "Peças de um mosaico...", da qual extraímos apenas as últimas linhas:

"Essa construção de territórios (e da sua conseqüente representação), dotados de tessituras sociais próprias pressupondo precisa territorialidade, estabeleceu marcos das identidades coletivas no universo luso-americano, tanto definindo (recorrendo à expressão de Anderson) as rotas de peregrinação, quanto os confrontantes nos quais essas identidades se espeIhavam."27

As muitas vezes em que Benedict Anderson, a partir do livro Nação e consciência nacional, aparece nas páginas do Independência é em razão desta perspectiva dos historiadores que buscam olhar os homens da América portuguesa, e suas múltiplas identidades, inseridos numa territorialidade que vai além das fronteiras político-administrativas. Residem aí diversas questões teóricas; uma delas é o fato de o historiador compreender que o estudo da política não se restringe à análise daquilo que é estritamente do universo da política - partidos, leis, eleições, governos etc. --, isto é, que as atitudes econômicas, culturais, sociais e religiosas, por exemplo, são percebidas como expressões de posicionamento político, por isso é que também deve ser captado o que se passa fora do espaço constituído oficialmente, pelo Estado, seja a vila, a província ou o Reino. Ao longo dos anos, por suas experiências nos lugares de mercadejar, de festejar, de receber e de passar informação, os homens vão construindo sensos de pertencimento e identidade. Essa maneira de entender o nascimento das identidades políticas resulta em parte de uma abordagem culturalista, a que voltaremos adiante.

Por esse e por outros motivos, foram muitos os autores do Independência que optaram por extrapolar os limites provinciais e apreender os grupos regionais projetados em cenários mais extensos, como Helga Iracema Landgraf Piccolo em "O processo de independência numa região fronteiriça: o Rio Grande de São Pedro entre duas formações históricas". 28 Segundo a professora, a fronteira obriga o estudioso da Independência no Rio Grande do Sul a olhar para as repercussões do que acontecia no Rio de 
29

Helga Iracema Landgraf Piccolo. "0 processo de Independência no Rio Grande do Sul" In: Carlos Guilherme Mota (org.). 1822: Dimensões. São Paulo: Perspectiva, 1986, p. 355-372.

\section{0}

Evaldo Cabral de Mello. O nome e o sangue. Uma fraude genealógica no Pernambuco colonial. São Paulo: Companhia das Letras, 1989.

\section{1}

Denis Antonio Bernardes. "Pernambuco e sua área de influência: um território em transformação (1780-1824)" In: István Jancsó (org.).

Independência, op. Cit., p. 386.
Janeiro e no Prata. Como há décadas observa o Rio Grande do Sul naquele período de esgarçamento dos laços coloniais - lembremos sua participação na obra 1822: Dimensões, organizada por Carlos Guilherme Mota e publicada em 1972-29, a professora Helga Piccolo pode ver como o comportamento político de vários grupos da elite do Rio Grande do Sul em favor do federalismo na época da Independência, e até anos depois dela, está vinculado a práticas que remontam ao período colonial, quando à Coroa portuguesa agradava o poder alcançado pelos potentados sulistas em virtude da apropriação das terras disputadas na região de fronteiras, onde os limites variavam bastante; os grandes senhores da região gozavam de larga autonomia, o que era tolerado pelo Estado metropolitano em nome da garantia do território em detrimento da Espanha.

Além de uma visão regional que ultrapassa as províncias, encontra-se aqui uma história da Independência que enraíza os homens num espaço de atuação mais concreto e menos oficial e, também, uma história que não se reduz apenas ao período curto, dos acontecimentos imediatos, rápidos, pouco antes e pouco depois da separação de Portugal. É a mesma visada de Denis Bernardes, que tomou para estudo uma "área de influência" em torno de Pernambuco e no diálogo com Evaldo Cabral de Mello de 0 nome e $o$ sangue ${ }^{30}$ sustenta que:

"As câmaras municipais, assim como a magistratura, a carreira das armas, o exercício de funções burocráticas, a carreira eclesiástica e mesmo o trato dos negócios, foram para muitos, ainda nos limites do Antigo Sistema Colonial, a oportunidade do exercício da experiência e da sociabilidade políticas." ${ }^{11}$ (grifos do autor)

Houve uma gradativa reordenação administrativa e territorial que expressava a crescente presença do Estado no universo colonial, inclusive com a incorporação dos membros das elites locais aos órgãos administrativos, o que vinha sendo proposto pela Coroa lusitana desde a época pombalina. A presença da Corte no Brasil intensificou ainda mais o processo de inserção dos colonos no Estado português e, portanto, aponta Denis Bernardes, não podemos atribuir pensamento e atitude política a estes homens somente a partir dos anos de 1821 e 1822; é preciso reconhecer sua longa experiência no trato de assuntos políticos durante o século XVIII e as primeiras décadas do XIX.

A experiência política dos homens da região pernambucana revelou-se com força no movimento revolucionário de 1817 - abortado por uma rigorosa repressão metropolitana - e reapareceu na experiência das Juntas de Governo de Pernambuco, da Paraiba, do Rio Grande do Norte, do Ceará e de Alagoas, entre 1821 e 1822, quando ficaram revigoradas suas esperanças constitucionalistas e o Antigo Regime arrefeceu. Por meio de reclamos e solicitações, a documentação originária das Câmaras e das ditas Juntas revelou ao historiador a participação de grupos das camadas mais baixas no encaminhamento das questões referentes à eleição dos membros para a Junta de Governo e para as Cortes de Lisboa. Muita gente variada, inclusive a mais pobre, ajudou a construir na área em torno de Pernambuco a crença no constitucionalismo, o que também implicava a defesa dos direitos do homem e do cidadão, além da autonomia dos poderes locais. Assim, Denis Bernardes mostrou que as transformações politicas naquela região, nas quais se envolveram estratos sociais diversos, giravam em torno do constitucionalismo e não do interesse na separação de Portugal, e que o apoio às 
Miriam Dolhnikoff. "São Paulo na Independência" In: István Jancsó (org.) Independência, op. Cit., p. 557-575.
33

Idem, p. 573

\section{4}

Ana Rosa Cloclet da Silva."Identidades políticas e a emergência do novo Estado nacional: o caso mineiro" In: István Jancsó (org.). Independência op. Cit., p. 515-555.

\section{5}

Wlamir Silva. Liberais e Povo: a construção da hegemonia liberal-moderada na provincia de Minas Gerais (1830-1834). Doutorado. Rio de Janeiro: Instituto de Filosofia e Ciências Sociais Universidade Federal do Rio de Janeiro, 2002.

\section{6}

Cláudia Damasceno Fonseca. Pouvoirs, villes et territoires. Gênese et représentations des espaces urbains dans lê Minas Gerais (Brésil), XVIIlèdébut du XIXè siécle. Doutorado. Paris: École des Hautes Études em Sciences Sociales, 2001.

\section{7}

Roberta Stumpf. Filhos das Minas, americanos e portugueses: identidades coletivas na capitania das Minas Gerais (1763-1792). Mestrado. São Paulo: Departamento de História, Universidade de São Paulo, 2001.

\section{8}

Carla Simone Chamon. Festejos imperiais. Festas cívicas em Minas Gerais (1815-1845). Bragança Paulista: Edusf, 2002.

39

Matthias Röhrig Assunção. "Miguel Bruce e os 'horrores da anarquia' no Maranhão, 1822-1827" In: István Jancsó (org.). Independência, op. Cit., p. 353.
Cortes lisboetas ou a um possivel governo de D.Pedro variou na medida em que estes garantiam um ambiente constitucional.

Em "São Paulo na Independência", 32 vemos que os grupos políticos mais fortes desta província foram os que se articularam em torno da monarquia constitucional. Conforme Miriam Dolhnikoff, professora da Universidade de São Paulo, desde a experiência de eleger e administrar das Juntas de Governo, a partir de 1820, foi se fortalecendo o desejo de autonomia entre a elite paulista. Distanciando-se gradativamente do projeto de José Bonifácio, a quem não escapava a necessidade de reformas sociais, um grupo de proprietários rurais fortemente enraizados na sua terra de origem participou do processo de Independência e de construção do Estado firmemente engajados na defesa da monarquia federativa. Num texto de boa leitura, límpido e bem estruturado, a pesquisadora indica as nuanças desse federalismo que não pressupunha fragilizar o poder central; foi a defesa da unidade das provincias sem ferir as autonomias regionais que proporcionou à plataforma dos liberais paulistas ganhar a adesão de muitas outras províncias desde as discussões nas Cortes de Lisboa. Decorrida quase uma década, o projeto deste grupo liberal paulista desaguou naquele dos liberais moderados e alcançou pleno sucesso em 1831, na abdicação de D.Pedro I, quando, então, conseguiram "a derrota simultânea de dois outros projetos distintos de Estado nacional: o da centralização imperial de D.Pedro I e o das reformas sociais, segundo o modelo europeu ilustrado, de José Bonifácio."33

$\mathrm{Se}$, de um lado, podemos extrair a defesa da autonomia regional, o constitucionalismo e o federalismo como possiveis linhas de força que caracterizaram as atuações das autoridades provinciais no processo de Independência, por outro, as especificidades não podem ser descuradas. As diversidades eram muitas entre as províncias do Reino americano e também no interior de cada uma delas. Ana Rosa Cloclet da Silva, em "Identidades políticas e a emergência do novo Estado nacional: o caso mineiro", 34 mostra com detalhamento cada uma das vertentes políticas que foram se delineando em Minas Gerais com a instauração do movimento vintista. Apoiada também em pesquisas recentes - teses e dissertações de Wlamir Silva 35 , Cláudia Damasceno Fonseca36, Roberta Stumpf37 e Carla Simone Chamon 38 -, apresenta como se posicionaram as autoridades locais em relação à nova ordem institucional, à propagação das idéias de liberdade e ao Príncipe no Rio de Janeiro. Parte dos proprietários e negociantes de Minas participava das vantagens econômicas e políticas trazidas pela proximidade com a Corte do Rio de Janeiro; nem todos, porém, estavam incluídos neste circuito, havia as localidades mais distantes dos caminhos para o Rio, cujos interesses e idéias eram distintos.

Matthias Röhrig Assunção lembrou que nos anos de 1820 a 1823 o poder provincial no Maranhão foi monopolizado pelos grupos mais próximos de São Luís, do qual ficaram excluídas as demais elites locais, o que também aconteceu em outras provincias. ${ }^{39}$ Em março e abril de 1822, como sabemos, o Príncipe visitou Minas Gerais. Suas andanças e o modo como foi acolhido naquelas vilas servem como exemplo da multiplicidade dos posicionamentos políticos; em algumas localidades foi tomado como aquele que garantia a ordem constitucional, noutras foi reconhecido como libertador do Brasil e, noutras, ainda, foi louvado por sua Majestade e por encarnar a realeza dos Bragança, em clara demonstração de apego aos valores do Antigo Regime. Temos aí, no dimensionamento e na caracterização da participação das autoridades e das camadas dominantes locais na 
40

Ana Rosa Cloclet da Silva. "Identidades politicas e a emergência do novo Estado nacional: o caso mineiro" In: István Jancsó (org.). Independência, op. Cit., p. 545.

41

Idem, p. 553.
42

Richard Graham."'Ao mesmo tempo sitiantes e sitiados'. A luta pela subsistência em Salvador (1822-1823)" In: István Jancsó (org.). Independência, op. Cit., p. 411-445.
43

Idem, p. 411
Independência, como indicou a própria Ana Rosa, um veio fecundo, ainda pouco explorado pelos historiadores.

Os propósitos de Ana Rosa Cloclet da Silva, entretanto, vão além da exposição da diversidade de tendências políticas. Tem em mira apurar algumas visões cristalizadas pela historiografia sobre o papel de Minas Gerais no nascimento do Estado nacional e esclarecer a construção da marca liberal moderada dos mineiros, que se consolidou na atuação que tiveram durante as décadas posteriores do Império brasileiro. Reduzindo o que foi apresentado pela autora, podemos afirmar que houve em Minas a gradativa conformação de um campo político de idéias para as elites que buscavam se defender, de um lado, dos riscos do "despotismo" - isto é, defender-se da perda das autonomias recentemente conquistadas, ou da retomada de poder dos potentados portugueses, ou da recolonização, ou do absolutismo do Príncipe - e, do outro, da "anarquia" - do terror dos grupos de escravizados, forros e outros pobres livres. Nas palavras da autora:

"Era, em outros termos, por negação a ambas as possibilidades que, progressivamente, aderiram à Monarquia Constitucional na figura de D.Pedro, reconhecendo-se com base em noções mais ou menos unificadoras, politizadas no decorrer da ruptura assinalada."40

As elites mineiras abrigaram-se em noções mais gerais, como "Pátria" e "Império", "à medida que estas embasavam projetos contemplativos de seus interesses específicos."41

Como se vê, a perspectiva de Ana Rosa Cloclet da Silva poderia ter feito seu texto, que foi alocado em A Independência nas partes do Brasil, ser incluído entre os da última fração do livro: Idéias e interesses. Do mesmo modo, os textos de João Fragoso, Marcus de Carvalho e Luiz Geraldo Silva - o primeiro, sobre as áreas do centro-sul, e os dois últimos sobre Pernambuco - poderiam figurar em A Independência nas partes do Brasil. Não dizemos com isso que se cometeram equívocos na estruturação do Independência: história e historiografia, mas que a complexidade da discussão sobre aquele período torna necessariamente múltiplas as abordagens de cada pesquisador.

Em meio a tantos homens públicos, correspondência oficial, discursos parlamentares etc., as páginas escritas por Richard Graham ${ }^{42}$ são um refresco para o leitor, pois ali se encontra uma análise minuciosa do abastecimento da cidade de Salvador durante os confrontos armados da Independência.

Para este pesquisador da Universidade do Texas, o especifico da Bahia foi ter sido encarada pelos portugueses e pelos grupos vinculados a D.Pedro como uma porção fundamental da América portuguesa, na medida em que se constituía numa área de ligação entre o Sul e o Norte. Para os portugueses, a manutenção da Bahia garantiria a incapacidade de o governo paralelo do Rio de Janeiro unir-se às províncias do Norte; os que apoiavam o Príncipe, por sua vez, entendiam que "sem a participação da Bahia, a Independência do Brasil mostrar-se-ia duvidosa ou, pelo menos, desprovida da unidade que os rebeldes do sul almejavam (...)".43 Por esta posição estratégica, então, a Bahia fez-se palco da guerra entre as tropas portuguesas e as forças que apoiavam D.Pedro. Richard Graham vê a falta de fornecimento de farinha como determinante no desfecho da luta, em julho de 1823, quando os portugueses recuaram. Segundo ele, os barqueiros, que eram homens cativos, forros, negros livres e brancos pobres, que abaste- 


\section{5}

Marcus J.M. de Carvalho."Os negros armados pelos brancos e suas independências no Nordeste (1817-1848)" In: István Jancsó (org.). Independência, op. cit., p. 881-914.

46

Clifford Geertz. Local Knowledge: Further Essays in Interpretative Anthropology. New york: Basic Books.

\section{7}

Edward P.Thompson. "The Moral Economy of the English Crowd in the Eighteenth Century" In: Costums in Common: Studies in Traditional Popular Cultures. New York: New Press, 1993.

\section{8}

Marcus J.M. de Carvalho. "Os negros armados pelos brancos e suas independências no Nordeste (1817-1848)" In: István Jancsó (org.). Independência, op. Cit., p. 913.

49

Idem, p. 891

50

Ibidem, p. 890.

51

Ibidem, p. 894

52

Ibidem, p. 892

53

Stuart Schwartz. Segredos internos. Engenhos e escravos na sociedade colonial. São Paulo: Companhia das Letras, 1988, p. 376. ciam a cidade de Salvador em tempos de paz, agora deixaram de fazê-lo, justamente quando os lusitanos lá se encontravam sitiados, isolados por terra. Não conhecemos de perto suas motivações, "Muitos, talvez a maioria dos capitães, seja por cálculo, por sentimento patriótico ou por temor de que suas tripulações pudessem denunciá-los, decidiram apoiar o lado brasileiro."44 (grifo do autor). 0 fato é que o comportamento desses homens dos grupos mais baixos da sociedade baiana decidiu a guerra, obrigando a retirada dos portugueses porque não dispunham de alimento para suas tropas.

Marcus J.M. de Carvalho, da Universidade Federal de Pernambuco, também está no campo dos enfrentamentos mais violentos, onde procura entender como surgiram as lideranças populares de Pernambuco no contexto da Independência, entre 1817 e 1848, da Insurreição de 1817 à Praieira. ${ }^{45}$ Bastante apegado às idéias de Clifford Geertz ${ }^{46}$ e Edward P.Thompson 47 , o pesquisador documenta como alguns dos homens dos estratos mais baixos, quando envolvidos nos conflitos armados que invadiram o Nordeste naquela época, mesmo se recrutados pelas forças ilegais, "terminavam politizados pelos acontecimentos".48 Segundo Carvalho, tratava-se de uma sociedade altamente marcada pela militarização, onde "através dessa assimilação de homens em armas o Estado se tornava uma realidade mais tangivel nas localidades" ${ }^{49}$ onde "Toda a população masculina adulta tinha um comandante."50 e onde "A história dos atos dos diferentes corpos de tropa, sob o comando tanto de civis como de militares, praticamente se confunde com a história política deste periodo." 51

Com os grupos polarizados em torno das questões referentes às autonomias local e provincial, aos centralismo e federalismo, e ao constitucionalismo, os confrontos armados, que de certa maneira espelhavam a crise da velha ordem política e institucional na região, antecederam e ultrapassaram o governo de D.João, o movimento liberal lusitano e o rompimento do governo do Rio de Janeiro com Portugal. Para manter a ordem, em todo o período foi preciso atrair - forçada ou voluntariamente - os escravos, os forros, os negros e pardos livres para dentro do aparato repressivo; ali, alguns desses homens puderam aprender a combater, a se organizar em grupo, a liderar; alguns deles, ao contrário do que se esperava, terminaram agentes da "desordem". Mostrar que tais homens transformaram-se politicamente pela experiência militar é uma das idéias mais interessantes e requintadas que se podem encontrar no Independência.

Ao se deparar com tantas e tão vigorosas resistências à ordem escravista na região em que estuda, Carvalho afirma que somente o caráter militarizado da administração do Brasil torna "possivel entender a manutenção da ordem senhorial escravista durante tanto tempo". 52 Lembremos, entretanto, da advertência de Stuart Schwartz ao afirmar que os historiadores brasileiros têm uma interpretação neopopulista quando sustentam que a independência não alterou a estrutura social do Brasil porque foi arquitetada pelas elites:

"(...)essa interpretação transfere o ônus da decisão politica para os grandes agricultores e comerciantes, a elite, e assim exime o 'povo' do pecado de perpetuar a escravidão. Sem dúvida a elite determinou a trajetória da independência política, mas o programa que formulou não era extrínseco ao contexto da sociedade brasileira como esta se desenvolvera no período colonial. De fato, um grande número de brasileiros participou da instituição da escravidão, ou ligou-se a ela de outro modo, e desejava - ou até mesmo ansiava por - sua continuidade."53 


\section{4}

Luiz Geraldo Silva. "Aspirações barrocas e radicalismo ilustrado. Raça e nação em Pernambuco no tempo da independência (1817-1823)" In: István Jancsó (org.). Independência, op. Cit., p. 915-934.

55

Idem, p. 925.

56

Pierre Bourdieu. "A gênese dos conceitos de 'habitus' e de campo" In: 0 poder simbólico. Lisboa: Difel, 1989

\section{7}

Norbert Elias. 0 processo civilizador. Formação do Estado e civilização. Vol.2. Rio de Janeiro: Jorge Zahar, 1993.

\section{8}

José Antônio Maravall. A cultura do barroco. Análise de uma estrutura histórica. São Paulo: Edusp, 1997.

\section{9}

Luiz Geraldo Silva."Aspirações barrocas e radicalismo ilustrado. Raça e nação em Pernambuco no tempo da independência (1817-1823)" In: István Jancsó (org.). Independência, op. Cit., p. 926

\section{0}

João Fragoso. Homens de grossa aventura. Acumulação e hierarquia na praça mercantil do Rio de Janeiro (1790-1830). Rio de Janeiro: Civilização Brasileira, 1998.

61

João Fragoso. "'Elites econômicas' em finais do século XVIII: mercado e politica no Centro-Sul da América lusa. Notas de uma pesquisa." In: István Jancsó (org.). Independência, op. Cit., p. 849-879.
Como notou Stuart Schwartz, arrisca não ficar em posição confortável o historiador que põe acento na atuação das camadas mais baixas no passado de uma sociedade plural como a nossa.

Luiz Geraldo Silva arriscou e saiu-se bem em "Aspirações barrocas e radicalismo ilustrado. Raça e nação em Pernambuco no tempo da independência (1817-1823)", 54 no qual analisou a participação dos "negros livres" nos conflitos armados pernambucanos entre 1817 e 1823. Segundo o pesquisador da Universidade Federal do Paraná, os "homens de cor" que tiveram posição de destaque nas forças militares não se formaram politicamente "apenas em decorrência de contatos com ilustrados radicais, mas em função das conversas nas oficinas artesanais, nas corporações militares, nos círculos familiares." $55 \mathrm{Em}$ arguta interpretação, parceira de Pierre Bourdieu56, Norbert Elias ${ }^{57}$ e José Antônio Maravall58, Luiz Geraldo Silva mostra como as práticas e as idéias daqueles "negros livres" encerravam um conflito:

"Por um lado, tais sujeitos incorporavam aspectos que notoriamente se reportavam à crítica ilustrada e radical à monarquia e a sua forma de governo e, por outro lado, mantinham vivas aspirações típicas de Antigo Regime - isto é, as clássicas aspirações barrocas referentes a cargos, promoções, privilégios e sinais de status e distinção social."59

No conjunto destas transformações, os homens pobres e os escravizados do Reino do Brasil, além de terem exercido um papel relevante como força que pressionava com suas sublevações os grupos de proprietários e senhores, fazendo-os temer o horror haitiano, lidaram com textos e idéias eminentemente políticas, como despontam alguns casos neste livro. Se, como afirmam alguns autores do Independência: história e historiografia, os textos camarários foram os depositários por excelência das demandas políticas dessa vasta e variada gente dos estratos mais baixos, provavelmente o exame de documentos de natureza judicial traria mais indícios de como migraram as idéias políticas para o seio da "populaça" e da escravaria, como se informavam a respeito dos acontecimentos e dos postulados liberais sejam autos de defesa como os analisados por Luiz Geraldo Silva ou mesmo inventários post mortem, como utilizados há anos por João Fragoso para entender as elites do Rio de Janeiro -. Até o momento, no que diz respeito à documentação oficial, os historiadores da Independência têm vasculhado sobremaneira os registros que circulavam no âmbito político-administrativo e legislativo, nas Câmaras, nas Juntas de Governo, nos parlamentos do Rio de Janeiro e de Lisboa etc. Seguramente, os autos judiciais revelariam ainda mais atuações individualizadas, trajetórias, falas e pensamentos políticos mais próximos do que foi a vivência dos pobres e dos cativos.

Desde Homens de grossa aventura João Fragoso60 tem examinado como poucos aquilo que na sociedade colonial não se reduzia à monocultura de exportação; mais do que isso, constituem grandes contribuições seus estudos sobre a formação das elites coloniais no Rio de Janeiro e as estratégias de enriquecimento, distinção e dominação por elas utilizadas, acompanhando algumas familias por gerações, levando em conta a composição de seus respectivos patrimônios, as posições e os cargos públicos que alcançavam. Fragoso, professor da Universidade Federal do Rio de Janeiro, continua no seu caminho de estudar as elites coloniais. No texto em questão, "'Elites econômicas' em finais do século XVIII: mercado e política no Centro-Sul da América lusa. Notas de uma pesquisa."," 61 trata 
62

Idem, p. 877.

63

Ibidem, p. 861

\section{4}

Ibidem, p. 853.

65

Ibidem.

66

Paul-André Rosental. "Construir o macro pelo micro" In: Jacques Revel (org.). Jogos de escalas. A experiência da microanálise. Rio de Janeiro: FGV, 1998, p.151-172. de compreender as estratégias utilizadas pelos distintos grupos das elites da América portuguesa durante o século XVIII. Na verdade, as famílias apresentadas estão enraizadas principalmente no Rio de Janeiro, em Minas Gerais e em São Paulo.

Para o autor, no século XVIII permaneciam como parâmetros da sociedade colonial:

"(...) uma hierarquia social tipo antigo, portanto, ciosa de suas diferenças, e em que a qualidade possuía um respaldo no cabedal; a interferência da política no mercado; e a sua natureza colonial, ou seja, o cotidiano americano presenciava negociações entre poder periférico e central." 62

Mudara, no entanto, o lugar do Rio de Janeiro na economia imperial lusitana, seja como importador e exportador das mercadorias originárias da Europa, seja como reexportador para a América dos produtos trazidos de variadas regiões do Império. Segundo Fragoso, tornou-se imperativo para as elites ao longo do Setecentos ampliar a envergadura das alianças políticas, de negócio e de família. De acordo com a circunstância histórica e com a dimensão de seus recursos, fossem as elites mercantis, fossem os que ocupavam os maiores postos da administração ou aqueles membros da velha "nobreza da terra", esses homens necessitavam muitas vezes atuar em dimensão imperial, alcançando uma área "supracapitanias" de influência social e mercantil, bem como a proximidade com os grupos que atuavam nos órgãos de administração metropolitanos.

"Não que os potentados locais tivessem desaparecido, porém, acima deles, as velhas alianças familiares supracapitanias adquiriam importância renovada, ou melhor, com o decorrer do século, a estratificação estamental colonial, progressivamente, assumia contornos que transbordavam a localidade."63

Ao final, Fragoso quer chegar à compreensão dos mecanismos de reprodução da sociedade colonial, ao funcionamento geral desta sociedade que, segundo ele, não servia apenas para sustentar o Antigo Regime e a aristocracia em Portugal. Mais uma vez, o professor quer demonstrar que as elites coloniais inseridas em redes clientelares interferiam nos circuitos mercantis imperiais; em suas palavras: "as redes imperiais tinham de contar, ou melhor, negociar com os vassalos americanos - personagens daquelas teias. Isso redefinia os mecanismos de transferência de recursos da Colônia para o Reino e, portanto, a própria dinâmica imperial."64

0 historiador promove esta análise por meio da "própria vivência dos circuitos ultramarinos"65 (grifo nosso). Recorrendo entre outros autores ao texto "Construir o macro pelo micro", de Paul-André Rosental, ${ }^{66}$ professor Fragoso também vai às "experiências", isto é, diminui a escala de análise para poder ver aquilo que se torna intangivel numa visada global. Sobre este ponto, é importante fazermos duas considerações.

A primeira não se dirige ao texto de João Fragoso diretamente, mas se vale de suas páginas para uma advertência aos que professam serem produtores de micro-história. Explicando melhor: na atualidade, há muitas teses e dissertações defendidas como sendo obras de "micro-história"; dispensamo-nos de tratar aqui do que venha a ser esta forma de produzir história, para o que recomendamos o mesmo Jogos de escala, citado por João Fragoso, mas cremos urgente lembrar que não nos torna micro-histo- 
67

Este seria um dos pontos de discordância em relação à micro-história de Carlo Ginsburg; vejam-se, sobretudo, no mesmo Jogos de escalas, os textos de Giovanni Levi e Edoardo Grendi.

\section{8}

João Fragoso. "'Elites econômicas' em finais do século XVIII: mercado e política no Centro-Sul da América lusa. Notas de uma pesquisa." In: István Jancsó (org.). Independência, op. Cit., p. 879
69

Cecilia Helena Salles de Oliveira. "Sociedade e projetos políticos no Rio de Janeiro (18201824)" In: István Jancsó (org.). Independência, op. Cit., p. 506. riadores o fato de abdicarmos de categorias rígidas e de perscrutarmos aquilo que está mais próximo do indivíduo ou de pequenos grupos para a explicação do passado - tomando suas "experiências" como objeto de análise, como fizeram grande parte dos historiadores do Independência: história e historiografia.

A segunda consideração que cremos importante fazer, embora sumária e ligeiramente, é sobre o uso do texto "Construir o macro pelo micro", em que Rosental reflete sobre os pontos de junção entre o método do antropólogo norueguês Fredrik Barth e a micro-história. Embora tenha atentado para a necessidade de se "identificar processos", sua ênfase está nas variações de comportamento dos sujeitos históricos, nas relações entre eles e na descrença no sistema normativo como forma de elucidar a sociedade. Da mesma maneira, os demais autores que escreveram sobre micro-história no Jogos de escalas insistem no valor da diminuição da escala de análise para o entendimento daquilo que escapa à coerência do sistema, para que o historiador possa apreender onde e como o sistema falha, onde a dominação não se realiza com eficácia. ${ }^{67}$ Trata-se, portanto, de perspectiva inversa à do professor Fragoso, que busca as "regularidades"68 como forma de entendimento da sociedade. Para ele, a participação dos homens da colônia nos negócios e na política, até os conflitos que se davam entre os diferentes grupos da elite, servem para mostrar o que garantia a "estabilidade do Império".

Nesta maneira de ver a história da Independência existe, portanto, um desenvolvimento linear no qual se assentam as grandes familias vencedoras do Rio de Janeiro e adjacências. Com o passar das décadas, o que houve foi o fortalecimento econômico e político que, como já sabiamos de princípio, levaria estes homens abastados ao centro de poder do Brasil nascente. Assim, não se permitem ver os potentados coloniais - mesmo os do Rio de Janeiro - que sofriam com as decorrências da condição colonial; nesta história, não há o que possa provocar rupturas, não há tributos excessivos, lentidão da justiça ou privilégios de reinóis que importunem as elites da luso-América. Em suma, apesar de contribuir imensamente para o estudo das elites coloniais por mostrar suas trajetórias nos negócios e nas alianças políticas e familiares, parece-nos que a interpretação que João Fragoso dá a essas "experiências" parte da necessidade de explicar o futuro daqueles tempos: o sucesso que o Rio de Janeiro alcançaria no cenário imperial lusitano a partir do Setecentos e no cenário brasileiro do Oitocentos.

De qualquer forma, os estudos mais recentes acerca do que se passou na região do Rio de Janeiro revelam facetas específicas do processo de Independência, ou seja, a história do Rio de Janeiro naquele período não é mais entendida como a história que, sozinha, explica o rompimento com Portugal. Apesar de ser um dos centros de decisão onde se debatiam os desdobramentos da crise da velha ordem política e institucional, apesar de ser a sede do Império a partir de 1808, o Rio de Janeiro abrigou peculiaridades, percursos que não se imbricavam com os das demais províncias. Conforme Cecilia Helena Salles de Oliveira, professora do Museu Paulista, "a reorganização da Corte portuguesa no Rio de Janeiro concentrou rendas e recursos do Estado nas mãos de poucas famílias, (...). 0 controle que esse grupo exercia acirrou as contradições de interesses (...)",69 deixando de fora da esfera pública muitos negociantes atacadistas, donos de engenho e proprietários de lavouras mercantis. Junto a esses grupos mais ricos, outros, de dentro e de fora da capital, como artesãos, rendeiros, foreiros e 
70

Kenneth Maxwell. A devassa da devassa. A Inconfidência Mineira: Brasil - Portugal 17501808. Rio de Janeiro: Paz e Terra, 1995. A primeira publicação da obra é de 1973, pela Cambridge University Press.

71

Kenneth Maxwell. Marquês de Pombal. Paradoxo do lluminismo. Rio de Janeiro: Paz e Terra, 1996, p. 153. posseiros ficaram também insatisfeitos com a normalização das atividades comerciais e da vida citadina, o que implicava em aumento de tributos, regras mais estritas para a produção manufatureira, diminuição da área de atuação no mercado etc.

As "lutas ferrenhas" entre as facções das elites regionais, apresentadas como uma característica das províncias do Norte pelos estudiosos, estavam presentes também nas disputas entre os grupos examinados por Cecilia Helena Salles de Oliveira; lembremos ainda daquelas dos potentados e magnatas de Minas Gerais, descritas por K.Maxwell desde A devassa da devassa.70 Ainda a propósito do comportamento das elites coloniais, valeria lembrarmos que neste livro e nos escritos posteriores Maxwell afirma que a inserção dos potentados locais nos órgãos administrativos do Estado português poderia garantir apoio mais efetivo às políticas metropolitanas enquanto os interesses imperiais e locais fossem coincidentes; caso as divergências crescessem, "poderia ocorrer exatamente o oposto."71

As lutas pelo poder local e regional, a violência dos conflitos e a participação das classes populares são apontados neste Independência como peculiares de Pernambuco, do Maranhão e do Pará, entre outras regiões. 0 resultado conjunto do próprio livro, no entanto, pede que se discuta a tomada dessas tais características como especificidades.

Por diversas razões, flexibilizaram-se as fronteiras entre o que considerávamos "específico" e "geral" na história da Independência. Primeiramente, porque os estudos regionais já trouxeram elementos que permitem configurar traços comuns na história de várias províncias do Reino americano naquele periodo. Ademais, os historiadores que se debruçam sobre 0 Rio de Janeiro já não o tomam como o centro a partir do qual se compreendem as atuações periféricas das demais regiões, ou seja, a história do Rio de Janeiro naquele período não pode mais ser vista como a história que não é específica. Por fim, mas subjacente a tudo, está uma perspectiva que aqui designamos "culturalista", que faz ver a atuação política dos homens do passado liberta das fronteiras político-administrativas, como indicamos acima, mas também em permanente interação na sociedade, isto é, trata-se sempre de um conjunto de experiências em que os sujeitos atuam simultaneamente manejando informações e atuações de outros agentes políticos; no limite, são práticas e representações políticas que se projetam e refletem entre variados grupos, o que nos permite trabalhar com mais elasticidade as noções de "centro" e "periferia".

Designamos de culturalista esta maneira de estudar o processo de Independência não somente porque queiramos enfatizar sua filiação à categoria "experiência" desenvolvida por E.Thompson; por isso também. Mas essencialmente porque estes historiadores da política estudam o passado ancorados em princípios que em grande medida vingaram primeiramente na antropologia e, depois, mais do que conformar o terreno daquilo que chamamos hoje de "história cultural", esses princípios atribuíram uma dimensão cultural a todas as expressões da vida social. Se, como dissemos, variados tipos de atuação em sociedade são percebidas como expressões políticas, podemos afirmar também que todas as atuações, nas diferentes esferas - econômica, política, religiosa etc. -, são tomadas como expressões de cultura e não hierarquizadas entre si a priori. A "experiência" - que não é exclusivamente thompsoniana, repetimos - é a forma pela qual a atuação política dos múltiplos sujeitos pode ser apreendida pelo historiador como multifacetada, como expressão dos arranjos e propostas em vista do futuro, 
72

Wilma Peres Costa."A Independência na historiografia brasileira" In: István Jancsó (org.). Independência, op. Cit., p. 53-118.

73

Idem, p. 108-109.
74

Veja-se o conceito de "experiência histórica" referido por João Paulo Pimenta na nota 1, à página 756, a partir de "'Espacio de experiencia' y 'horizonte de expectativa', dos categorias históricas", da obra Futuro pasado: uma semântica de los tiempos históricos: "um conjunto de fatos, imagens e exemplos passados apreendidos e reelaborados no presente tendo em vista projeções de futuro; e, ao mesmo tempo, como um conjunto de situações presentes perante as quais algumas mobilizações subsidiam, igualmente, aquelas projeções." das condições materiais e dos quadros mentais em que estão inseridos. Daí o uso recorrente do termo "cultura política". De resto, veja-se o "A Independência na historiografia brasileira", da professora Wilma Peres Costa, ${ }_{1}^{72}$ no livro aqui apresentado, sobretudo a parte denominada 0 espaço público: ampliação da esfera da política:

"O desprestígio das versões lineares e mecanicistas do marxismo teve, nesse campo, efeito salutar, no sentido em que o universo dos fatos políticos passava a ser pensado como objeto dotado de luz própria. Ao mesmo tempo, as relações entre a esfera da vida material e as da dinâmica politica deixavam de ser concebidas como dadas, para ser encaradas como problemas de investigação, a serem tratados no plano da pesquisa documental e da singularidade das experiências históricas."73

Esta perspectiva de investigação é a que nos faculta tomar como objetos - e, às vezes, abordagens - de estudo os elementos da "cultura política do Antigo Regime português": a fidelidade dos súditos para com o rei, a ordem hierárquica da estrutura social, as identidades dos que pertenciam à Nação portuguesa. Em síntese, os historiadores recentemente têm descoberto na leitura dos documentos, no exercício mais elementar de sua profissão, que a sociedade do final do século XVIII e início do XIX, na Península Ibérica e na América portuguesa, organizava-se, objetivamente, de maneira distinta daquela que os seus colegas acreditavam há cerca de trinta anos; simultaneamente a esta nova configuração política que é encontrada no passado, os historiadores estão mais "culturalistas", mais desapegados de categorias explicativas rígidas e generalizantes, o que os torna mais livres para apreenderem a alteridade da expressão política dos que viviam nos estertores do Antigo Regime. Estes dois elementos da questão - a realidade passada tal como é vista hoje e o modo como o historiador a observa - são muito parecidos e contíguos, mas não são a mesma coisa.

Deixando de lado as importantes discussões que poderiam iluminar esta relação de reciprocidade, de subordinação ou de anterioridade entre os pressupostos teóricos de um cientista social e a realidade por ele examinada, cremos ser imperativo alertar para o fato de que o historiador não pode desconhecer ou desprezar essa distinção que apontamos. Se o pesquisador ignora que é a sua maneira de olhar, diferente daquela de algumas décadas atrás, compartilhada por seus colegas contemporâneos, que ajuda a chegar mais perto da vivência e do significado da política dos homens que participaram da crise do Antigo Regime, tende a manejar as novas categorias de análise com ingenuidade, deixando de desconfiar dos documentos e chegando a tornar abstratos e absolutos - porque rígidos, generalizantes, incontestáveis e imutáveis - termos como "Antigo Regime", "Império", "privilégios", "nobreza", "distinção" etc.

Pelo modo como problematizam suas abordagens e pelos diálogos que estabelecem com as obras de E.Thompson, P.Rosanvallon, C.Geertz, P.Bourdieu, R.Chartier, R.Darnton e R.Koselleck, ${ }^{74}$ a maior parte dos autores do Independência tem assegurada a versatilidade que Ihes permite lidar com as ambigüidades de um mundo que era lusitano e ao mesmo tempo colonial, do Antigo Regime e simultaneamente ilustrado, protecionista e liberal, isto e também escravista, e ainda com as muitas gradações que existiram entre esses pólos. Para estes historiadores, os distintos grupos que viveram deste lado do Atlântico no século XVIII e no início do XIX estavam imersos em realidades materiais, pertenciam a determinadas tradições culturais e, de muitas maneiras, elaboravam projetos de futuro. 
75

Marco Morel."Independência no papel: a imprensa periódica" In: István Jancsó (org.). Independência, op. Cit., p. 617-636.

\section{6}

Idem, p.618.

77

Ibidem, p.621.
As idéias e os discursos políticos na época da Independência

Além do que já vimos, esta forma "culturalista" de tratamento das expressões políticas pressupõe limites fluidos entre suas faces prática e mental, entre a atuação e a representação. Mesmo sabedores de tal fluidez, alguns historiadores vasculham precipuamente no terreno das representações; menos voltados para a atuação política, investigam a propagação das idéias e 0 aspecto que elas adquirem no discurso dos diferentes grupos sociais. Vejamos, então, alguns textos que são inovadores nesta abordagem e, além disso, trazem contribuição relevante para a história política do fim do periodo colonial.

Vários autores do Independência: história e historiografia assinalam a defesa da autonomia regional como o traço que explica o comportamento político das partes do Brasil ao longo do processo de Independência. Em algumas paragens essa luta pela manutenção da autonomia chegou a se definir nos termos do constitucionalismo e/ou do federalismo. A atuação das autoridades provinciais e o modo como estas se movimentaram em torno das Cortes de Lisboa e do governo do Rio de Janeiro assentam num percurso que começa antes do grito do Príncipe - em alguns artigos, bem antes - e vai terminar anos depois de a separação de Portugal ter se consumado. De toda maneira, os historiadores constróem uma seqüência de eventos que não se compreende em função do ocorrido em setembro de 1822, tampouco de interesses políticos anti-coloniais ou separatistas.

Dai o interesse que desperta o texto "Independência no papel: a imprensa periódica", de Marco Morel. ${ }^{75}$ Na parte do livro denominada Instrumentos da política, este pesquisador da Universidade Estadual do Rio de Janeiro assevera com expressividade: "A discussão sobre a possibilidade de separação da América portuguesa do Reino de Portugal ocorre ainda na década de 1810, também na imprensa periódica redigida em português que circulava no território brasileiro."76 Eram correntes nas leituras dos homens letrados e de vida pública no Brasil os livros dos abades franceses Guillaume-Thomas Raynal (1713-1796) e Dominique-Georges-Fréderic De Pradt (1759-1837), que continham reflexões sobre a situação colonial da América portuguesa e seu provável destino. Segundo Marco Morel, as obras dos ditos clérigos foram apresentadas e discutidas nos jornais do Brasil, e correspondiam a

"(...) dois modelos de independência: um (Raynal) valorizando a noção de soberania popular, prevendo a ruptura dos laços com as metrópoles e chegando até a abolição da escravidão e outro (De Pradt) trilhando a via de reformas graduais sem maiores rupturas da ordem política e social."77

Examinando mais detidamente a crítica que o redator do Correio Braziliense, Hipólito da Costa, em 1817, fez ao livro recém-publicado de De Pradt, Des trois derniers mois de l'Amérique méridionale et du Brésil. Suivis des personnalités et incivilités de la quotidienne, Morel também apresenta outros artigos, da Gazeta do Rio e do Revérbero Constitucional Fluminense, em que se contesta a posição do abade De Pradt, por sua vez baseada em bons e variados argumentos em prol da idéia de que a separação do Brasil de Portugal tornara-se inevitável depois da transferência da Corte para o Rio de Janeiro. Por meio desses casos apanhados na imprensa fica então evidente a existência do debate acerca da ruptura com Portugal, o fato de esta possibilidade ter-se colocado ainda na década de 1810 para aqueles que participavam do nascente cenário da opinião pública na América portuguesa. 
78

Ibidem, p.628

79

Lúcia Maria Bastos Pereira das Neves."Os planfletos políticos e a cultura política da Independência do Brasil" In: István Jancsó (org.). Independência, op. Cit., p. 637-675.

80

Idem, p.657 e p.663.

81

Márcia Regina Berbel."A retórica da recolonização" In: István Jancsó (org.). Independência, op. Cit., p. 791-808.
0 historiador da UERJ apreende a contenda sobre o rompimento entre os dois reinos, mas indica que os postulados do abade De Pradt foram sempre refutados, ainda que recorrentes na imprensa do Brasil naqueles tempos. Diferenciando-se de outros pesquisadores do livro, Morel antecipa em alguns anos a discussão sobre a possibilidade de o Brasil se separar da Monarquia portuguesa e se diz instigado com a

"(...) decalagem entre parcela dos homens de letras e da politica 'brasileiros' e este abade francês, durante duas décadas, sobre a Independência do Brasil de Portugal: aqueles contrários e procurando evitá-la, este se mostrando favorável e com certeza inabalável de seu advento."78

Não obstante a dita discussão que se deu na imprensa e as expressões mais radicais da crise política - como a Revolução de 1817, em Pernambuco -, devemos observar que os estudiosos permanecem convencidos de que a Independência precedeu a Nação, para usarmos o mesmo vocabulário de Marco Morel no encerramento de seu "Independência no papel". Isto quer dizer que não têm sido encontrados laivos nacionalistas nos embates que se deram naqueles anos e que o processo de construção da nação brasileira deve ser investigado em período posterior ao do rompimento com Portugal. Para esta matéria o melhor é recorrer ao Brasil: Formação do Estado e da Nação, também organizado pelo professor István Jancsó e publicado pela Hucitec em 2003.

Por meio da análise de muitos panfletos, folhetos e jornais dos anos de 1821 e 1822, notadamente daqueles que foram veiculados no Rio de Janeiro, Lúcia Pereira das Neves, ${ }^{79}$ também da UERJ, depois de observar os debates caminharem no sentido do constitucionalismo para o separatismo, apreendeu uma "outra leitura da Independência", onde o centro das discussões estava nos "fatores políticos", pois não havia nos tais escritos referências sobre as relações comerciais entre Brasil e Portugal, sobre as supostas retomadas do exclusivo colonial. Esse novo ideário das coisas políticas criava uma esfera de discussão do poder, nos ambientes agora públicos, e expressava-se em variadas posições que caminharam aceleradamente, em confronto ou em paralelo. Para a autora, tratava-se de uma cultura política ilustrada multifacetada que prosperara entre as "elites política e intelectual" deste lado do Atlântico e que as fez sentirem-se responsáveis por participar da nova situação política no Brasil, onde, mesmo depois da Independência, apesar das leis e dos órgãos representativos, mantiveram-se muitas práticas políticas do Antigo Regime. Nos anos e nos panfletos em questão, os discursos políticos defenderam a preservação do Império luso-brasileiro, a reunião de duas coroas independentes, de Portugal e do Brasil, mas unidas num mesmo Império, e, nos meados de 1822, chegaram a propor um Estado independente; tais postulados não se apresentaram necessariamente nessa ordem cronológica, mas num arranjo conflituoso em que a polarização Brasil/Portugal, mais precisamente o "separatismo" entendido como a ruptura toral, segundo a autora, foi provocado pelas "atitudes intransigentes das Cortes portuguesas em relação ao Brasil".80

Num texto claro e preciso, nascido como desdobramento de seu livro A nação como artefato, a professora do Departamento de História da USP, Márcia Regina Berbel, 81 mostra como desde as últimas décadas do século XIX veio se consolidando entre os estudiosos a idéia de que nas Cortes de Lisboa, ao longo da experiência constitucional portuguesa, entre 1821 e 1822, formulou-se um projeto de recolonização do Brasil que, tendo agudi- 
82

Sérgio Buarque de Holanda."A herança colonial - sua desagregação" In: História Geral da Civilização Brasileira. Brasil monárquico. São Paulo: DIFEL, 1985, p. 9-39.
83

Márcia Regina Berbel. "A retórica da recolonização" In: István Jancsó (org.). Independência, op. Cit., p. 807. zado os conflitos entre os representantes de Portugal e os das províncias do Brasil, tornou inevitável a separação entre os dois reinos. Para Márcia Berbel, no entanto, pode-se rediscutir essas interpretações consagradas a partir de nova leitura dos discursos contidos no Diário das Cortes Constituintes. Segundo ela, antes de serem recolonizadoras, as propostas dos deputados portugueses eram integracionistas, pois supunham o fortalecimento do poder central sediado em Lisboa, com capacidade para intervir nas muitas partes da monarquia e constituir fortes laços político-administrativos, para manter sólida a unidade nacional. Por rejeitarem as demandas de autonomia que havia no Congresso e defenderem o fortalecimento do poder central, as políticas dos deputados de Portugal foram tomadas como recolonizadoras pelos deputados do Brasil.

A autora interpreta muito bem o significado daqueles discursos, superando 0 anacronismo de algumas análises que sempre entenderam como contraditório o liberalismo oitocentista, fosse de portugueses ou de brasileiros. Para tratar da construção do Estado no Brasil independente, portanto de um período imediatamente posterior àquele estudado neste texto por Márcia Berbel, Sérgio Buarque de Holanda em "A herança colonial - sua desagregação"82 apontou o equívoco de entendermos a proposta de descentralização como uma política mais progressista do que a de centralização. Afirmava o professor Sérgio que para os liberais que viviam no século XIX, principalmente os de inspiração francesa, manter as autonomias locais e/ou regionais era ser conservador, enquanto que fortalecer o poder central significava homogeneizar procedimentos administrativos e extirpar privilégios próprios do Antigo Regime. Resguardadas as diferenças das realidades estudadas, é alentador perceber que a perspicácia daquele estudioso não permaneceu soterrada pelas muitas obras dos meados do século XX, em que os historiadores, na ânsia de serem críticos das "elites nacionais", teimavam em analisar pela rama o conteúdo liberal do processo de independência e do nascimento do Estado brasileiro. De resto, os estudos sobre a Independência têm mostrado que os debates estavam mais concentrados nas muitas propostas para a monarquia constitucional e não na polarização unidade e separatismo como a historiografia apregoou durante décadas.

A opinião de Márcia Berbel apóia-se não apenas nas questões políticoadministrativas, mas no exame dos debates congressistas acerca do envio de tropas portuguesas para a América, da nomeação dos governadores das armas e também da política econômica, cujas discussões, conforme a autora, iniciaram-se apenas em abril de 1822. Mais ainda, na leitura atenta que faz do Diário das Cortes, percebe o mesmo que Lúcia Pereira das Neves encontrou no material escrito que circulava no Rio de Janeiro nos anos anteriores à separação de Portugal: as questões econômicas não eram o cerne das divergências entre brasileiros e portugueses, pelo menos não da maneira como nos fizeram crer muitos dos que estudaram aquele período. Segundo a historiadora da USP, não emergiu no debate uma proposta para a formação de mercado interno no Reino do Brasil e a demanda era por garantir a integração de cada província no mercado internacional; o essencial das discussões estava "no tipo de política econômica a ser adotada para o conjunto do Império e qual o papel a ser exercido pelo Estado na implementação dessa política".83 As coisas não eram discutidas em termos de Brasil e de Portugal, mas do Império; entretanto, num determinado momento, os brasileiros viram como retorno do exclusivo colonial as tentativas de manter o controle estatal do comércio e centralizá-lo em Lisboa. 
84

Helga Iracema Landgraf Piccolo. "O processo de independência numa região fronteiriça: o Rio Grande de São Pedro entre duas formações históricas" In: István Jancsó (org.). Independência, op. Cit., p. 590-591.

85

Ana Cristina Araújo."Um império, um reino e uma monarquia na América: as vésperas da Independência do Brasil" In: István Jancsó (org.). Independência, op. Cit., p. 235-270.
86

Idem, p. 250 .
Assim, em "A retórica da recolonização", ao fechar o foco e diminuir o período de análise, amplificando os discursos políticos e conferindo-Ihes a alteridade necessária a seu bom entendimento, ou seja, ao examinar as idéias políticas na historicidade do curto momento em que eram veiculadas nas Cortes de Lisboa, sem cobrir as propostas do decreto de outubro de 1821 com o significado que passaram a ter em agosto de 1822, por exemplo, Márcia Regina Berbel garante um avanço para a compreensão do papel desempenhado pelos enfrentamentos que se deram nas Cortes no processo de separação de Portugal. A recolonização, longe de contemplar o que pretendiam os parlamentares portugueses - o integracionismo e o fortalecimento do poder central em Lisboa -, foi um instrumento de retórica daqueles que representavam o Brasil nas Cortes e que viam frustradas as suas pretensões de autonomia.

Há muito está patente que os tempos do Antigo Regime e os de sua crise requerem atenção do pesquisador para a alteridade de seu repertório político; mas isso não basta. Nos anos e meses que compõem o período de rompimento com Portugal, as transformações são tantas e tão rápidas e singulares que a argúcia é imprescindivel ao historiador que queira manejar o vocabulário político coevo. Em algumas províncias, a defesa da centralização político-administrativa, fosse oriunda das Cortes de Lisboa ou do Rio de Janeiro de D.Pedro, era chamada de "despotismo", entendida como ranço absolutista. Inúmeras vezes os mais conservadores atribuíram "anarquia" como pecha à gente miúda rebelada ou àqueles que prontamente aderiram ao vintismo. Nas muitas páginas do Independência: história e historiografia há dezenas de casos em que os historiadores revelam ao leitor os muitos significados por que passaram certas idéias e enquadramentos políticos em tão pouco tempo. Assim é que vemos um homem ser detido na província em que vive e encaminhado ao Rio de Janeiro por ter pregado a "independência do Brasil"; ao chegar à Corte, no entanto, a acusação que lhe pesava perdera o sentido, pois viviam o dia do Fico. ${ }^{84}$ Antes disso, a transferência da sede do governo português para o Rio de Janeiro e a criação do Reino Unido provocaram deslocamentos inauditos no universo político do que se entendia por monarquia e por império no contexto do Antigo Regime, como mostra Ana Cristina Araújo, da Universidade de Coimbra, em "Um império, um reino e uma monarquia na América: as vésperas da Independência do Brasil", 85 um dos mais instigantes trabalhos apresentados neste livro.

Após as quinze páginas em que apresenta a formação de uma esfera pública de discussão política na América portuguesa ao longo das últimas décadas do Setecentos, a pesquisadora de Coimbra afirma que vê um caráter revolucionário nas idéias que sustentaram o pensamento ilustrado das elites da América portuguesa naqueles tempos luso-brasileiros; vê ainda que:

"(...) apesar do caráter restrito da difusão das idéias revolucionárias na Colônia, é da América portuguesa que partem os primeiros e mais inquietantes sinais de descontentamento político e é para lá que a Corte portuguesa se dirige na tentativa de travar a desintegração política do Império, igualmente ameaçado do exterior."

Na sofisticada reconstrução das mudanças políticas e econômicas que impregnaram a transferência da Corte, o fim do exclusivo colonial, o tratado de comércio de 1810 e a criação do Reino Unido, fica evidente que o ponto de vista peninsular da pesquisadora permite apontar as rupturas que, pouco a pouco, vão se processando e levam à implosão do Império 
87

Ibidem, p.264.

88

Ibidem, p.269-270.

89

Andréa Slemian. "Seriam todos cidadãos?: os impasses na construção da cidadania nos primórdios do constitucionalismo no Brasil (18231824)" In: István Jancsó (org.). Independência, op. Cit., p. 829-879. português. 0 que para os pesquisadores brasileiros se constitui num complexo de idéias e de interesses políticos que aos poucos se fortalecia para gerar diversos arranjos e projetos, em boa medida conservadores, que muito variava conforme a região, para quem vê do outro lado do Atlântico adquire mais coerência e unidade no sentido de provocar o rompimento dos laços coloniais e da monarquia portuguesa.

Entre outras alterações, a inexistência de demandas portuguesas na política externa do governo do Rio de Janeiro - o que criava impasses para os portugueses diante da Espanha e das demais nações da Europa - e a duplicação do aparelho central do Estado no Reino americano corroiam a coesão do Império. Quanto mais fiéis os brasileiros se faziam aos Bragança, mais contrários ao colonialismo se apresentavam, pois estreitavam os laços que prendiam o rei ao território do Reino do Brasil. Conforme Ana Cristina Araújo:

"Usado para travar a desagregação histórica do Império e a cisão da casa reinante de Bragança, dividida entre dois Estados com a mesma chancelaria, a institucionalização do Reino Unido substancia, no plano simbólico, a decadência de um sistema imperial e a fraqueza política de um regime." 87

No escudo real, a esfera que indicava a universalidade do domínio português foi atribuída como símbolo distintivo do Reino do Brasil em maio de 1816. Em Portugal, no entanto, negaram-se a usar o dito escudo nos papéis oficiais.

No último parágrafo do texto, depois de ter apresentado uma polêmica que se deu em Portugal no ano de 1821 em torno das propostas de monarquia constitucional e dual, assevera Ana Cristina Araújo:

"Em suma, a questão brasileira, levantada pelo novo quadro de relações de (in)dependência dos dois reinos, constitui-se em pedra angular da crise do sistema colonial, projetando, como num jogo de sombras, os elos de raiz histórica e doutrinal da moderna construção ideológica do EstadoNação."88 (grifo da autora).

Se os historiadores brasileiros têm cuidado para não acentuar uma presença anacrônica do "Brasil" no andamento das transformações políticas daquele período de desintegração do Antigo Regime, se têm cuidado para não incorrer numa história de teor nacionalista, Ana Cristina Araújo, de Coimbra, vê a conformação e o fortalecimento do Reino do Brasil como incompatíveis com o corpo político imperial, um constructo do Antigo Regime.

0 texto de Andréa Slemian, 89 por se debruçar sobre a primeira experiência constituinte do Brasil - iniciada em 3 de maio de 1823, interrompida em novembro deste mesmo ano e convertida na carta outorgada em 1824 - talvez estivesse melhor se alocado na coletânea anterior deste grupo de pesquisadores, Brasil: Formação do Estado e da Nação, citado anteriormente; mas são indiscutíveis os laços que unem suas reflexões às do conjunto deste livro sobre a Independência.

Invocando Roderick Barman em Brazil: The Forging of a Nation, 17981852, a pesquisadora da Universidade de São Paulo lembra que a decisão de convocar uma Assembléia Constituinte em começo de junho de 1822, três meses antes, portanto, da proclamação do príncipe, "contribuiu muito para a adesão que provincias e câmaras fariam ao projeto de Independência, 
91

Gladys Sabina Ribeiro. A liberdade em construção. Identidade nacional e conflitos antilusitanos no Primeiro Reinado. Rio de Janeiro: Relume Dumará, 2002

\section{2}

Keila Grinberg. 0 fiador dos brasileiros.

Cidadania, escravidão e direito civil no tempo de Antônio Pereira Rebouças. Rio de Janeiro: Civilização Brasileira, 2002

\section{3}

José Murilo de Carvalho. Cidadania no Brasil. 0 longo caminho. Rio de Janeiro: Civilização Brasileira, 2003

\section{4}

Richard Graham."Dimensiones de la ciudadanía en el Brasil del siglo XIX" In: Hilda Sábato. Ciudadanía politica y formación de las naciones. Perspectivas históricas de América Latina. México: Fondo de Cultura Econômica, 1999, p. 345-370. No texto em análise, ver p. 832-ss.

\section{5}

Andréa Slemian."Seriam todos cidadãos?: os impasses na construção da cidadania nos primórdios do constitucionalismo no Brasil (18231824)" In: István Jancsó (org.). Independência, op. Cit., p. 831

96

Idem, p.841.

97

Ibidem, p.846. animadas com a perspectiva de que seus interesses locais fossem contemplados na construção de uma nova ordem."90 Para os leitores, lembrar que o processo constituinte encerrado em 1824 iniciara antes da Independência evidencia como os historiadores têm privilegiado abordagens políticas que não apenas fazem submergir o 7 de setembro, com todas as implicações que disso decorrem, principalmente no que diz respeito ao ocultamento do papel do príncipe D.Pedro - ausência recorrente nos textos recentes acerca do período -, mas também têm privilegiado abordagens que realçam as linhas de força de "construção de uma nova ordem", como afirmou a autora, isto é, focam o debate político estabelecido com o esfacelamento do Antigo Regime, no que trazia de novidades no plano das leis, da origem e da natureza do poder político e da igualdade dos homens em sociedade.

Além de fazer o mesmo que outros autores deste livro, que trataram o constitucionalismo como um elemento central nos embates que levaram à implosão do Império português, Andréa Slemian ainda discute nas páginas iniciais outro tema caro aos textos do Independência: história e historiografia: o das possiveis incongruências do liberalismo brasileiro no Oitocentos, que aqui teria sido plantado como estrangeirice no terreno impróprio da sociedade escravista. Segundo a autora, a opinião de inadequação e contradição do liberalismo brasileiro já não se sustenta porque a revisão que os estudiosos têm proposto nas últimas décadas permite-nos afirmar, entre outras coisas, que o liberalismo europeu no século XIX ainda não tinha garantido igualdade política e social para todos os que viviam sob as constituições modernas, nem mesmo para os que habitavam a França. No âmbito do Brasil, o exame minucioso das práticas de escravos e forros, promovido por Gladys Sabina Ribeiro91 e Keila Grinberg92, por exemplo, mostra que esses grupos exerceram pressão e reivindicaram anseios fazendo uso dos caminhos abertos por esta nova ordem institucional e jurídica criada com a Constituição de 1824. Logo, continua Andréa Slemian, o caráter liberal que impregnava o país nascente não era "letra morta", tampouco se constituíra "de cima para baixo", como conceberam José Murilo de Carvalho ${ }^{93}$ e Richard Graham ${ }^{94}$.

Investigando com perícia o que ficou registrado no Diário da Assembléia Geral Constituinte e Legislativa do Império do Brasil, a pesquisadora se propõe a tratar dos "problemas que estiveram presentes na construção desse 'cidadão brasileiro' na primeira experiência constituinte moderna no Brasil."95 Nos discursos parlamentares, cruza os muitos conteúdos que se foram atribuindo aos termos "brasileiro" e "cidadão", bem como as prerrogativas que a eles se associavam. Aos poucos, vão sendo desemaranhadas para o leitor, como aconteceu para os próprios constituintes, as noções de nacionalidade e de cidadania; vão sendo separados os direitos políticos dos demais.

Assim é que se chegou à solução de que "todos os 'brasileiros' fossem considerados 'cidadãos brasileiros'. Essa era uma forma de evitar que todos os 'habitantes' fossem confundidos com os 'cidadãos'."'96 Quanto aos portugueses, ficou decidido que se tornavam cidadãos brasileiros os que residiam no Brasil antes da aclamação de D.Pedro, em 12 de outubro de 1822, e que não fossem contrários à nova ordem política. Quanto aos que não eram brancos, a gente escravizada e a liberta, Andréa Slemian ousa uma nova interpretação, apontando a ambigüidade da forma definitiva do texto constitucional, que integrou os libertos ao conjunto dos cidadãos: de um lado, essa integração "reforçava, em seu contexto, a distinção entre o mundo dos homens livres e o dos escravos e visava, (...), a manutenção da estabilidade desse sistema"97; de outro,"apesar das dificuldades que existiram aos ex- 
Ibidem, p.847. cativos no alcance dos seus plenos direitos de cidadania, (...), a dissociação entre sua posição social e política de critérios raciais, como a que vingou na Constituição, fazia que os ditos direitos que compunham o universo dos cidadãos pudessem ser almejados no seu horizonte de expectativa."98 $\mathrm{Ou}$ seja, Andréa Slemian apreendeu nos debates constituintes e no resultado a que chegaram em 1824 o arcabouço jurídico no qual outros historiadores têm documentado a movimentação política das camadas mais inferiores do pais que acabava de nascer.

Depois de convivermos por muito tempo com obras historiográficas sobre a Independência cujo teor crítico residia na insistência da continuidade dos traços coloniais, atualmente os pesquisadores estão mais dispostos a enfrentar os dilemas de quem busca perceber o que mudou e o que permaneceu na passagem da colônia para o Império do Brasil. Pensamos que isto está estreitamente vinculado a uma maneira peculiar de lidar com o tempo.

É evidente que esta discussão carece de maior profundidade e fôlego; aqui, apenas pretendemos esboçá-la e, por meio de seu tratamento ligeiro, otimizar o entendimento do que foi produzido pela maior parte dos historiadores deste livro, explicitar os pressupostos que fazem dele uma valiosa contribuição para a historiografia da época da Independência.

Insatisfeitos com as explicações totalizantes, os historiadores, como os demais estudiosos das ciências sociais, rejeitaram as visadas mais gerais e abstratas, buscando chegar mais perto das vivências dos diversos sujeitos históricos. Para chegar à concretude de suas atuações e à alteridade de sua cultura política foi preciso diminuir a escala de análise e, igualmente, encurtar os períodos para apreender os acontecimentos. Gostariamos de considerar três pontos acerca desse tratamento do tempo na história política do final do período colonial.

0 primeiro é que o encurtamento dos períodos, que gerou estudos mais pormenorizados e análises bastante verticalizadas, fez-se em repúdio ao anacronismo e à linearidade da história de cunho nacionalista, em que a nação precedia a Independência. Entretanto, ainda que os períodos de análise estejam reduzidos a poucos anos, buscam-se em tempos bem mais extensos o significado dos variados elementos que neles são encontrados; as atitudes e os discursos políticos ocorridos nos eventos de 1820 a 1824 são interpretados à luz da crise do Antigo Regime, portanto, do desmantelamento de uma "cultura política" cuja duração remonta a séculos.

0 segundo ponto a considerarmos é vizinho do primeiro. Forçar as tintas na efervescência política dos anos imediatamente anteriores e posteriores ao 7 de setembro, permitiu melhor observar o que era publicado na imprensa, discutido nos novos espaços urbanos de sociabilidade, nas Juntas de Governo, nas Cortes de Lisboa, nas Câmaras etc. Romper com a linearidade da história possibilitou aos historiadores compreenderem as circunstâncias políticas da Independência sem incorrerem no anacronismo, porque se desprenderam do futuro daquelas mesmas circunstâncias. Contudo, há que se perguntar: e o passado que não é o de longa duração, que é o daqueles meses e anos que antecederam o rompimento com Portugal? Como alertou Denis Bernardes no texto que examinamos acima, não podemos desprezar as décadas anteriores de vivência política daqueles homens em colônia.

A intenção de compreender as experiências políticas da crise do Antigo Regime no Império português levando em conta as estruturas 
Ver "Independência, independências", p. 21, em que, por meio de Joaquim Romero de Magalhães, professor István Jancsó alerta para a diferença de ritmos na sociedade portuguesa do Antigo Regime.

100

Como eram chamados à época os homens livres pobres. Ver "Independência, independências", p. 40-42, em que o professor István Jancsó discute o tratamento dado pelos historiadores ao maior contingente humano da população da América portuguesa.
101

Lúcia Maria Bastos Pereira das Neves. "Os planfletos políticos e a cultura política da Independência do Brasil" In: István Jancsó (org.). Independência, op. Cit., p. 655-656. materiais, a hierarquia social e os quadros mentais nos quais estavam inseridas requer a percepção de múltiplas temporalidades, o que vem a ser nosso terceiro ponto. 99

A idéia de nação exemplifica como há traços da cultura política que se originaram em tempos mais remotos e que estão sob o enquadramento do Antigo Regime, e que outros elementos, no entanto, têm mais frescor, remontam às décadas anteriores e filiam-se ao liberalismo europeu.

Sabemos que levaria algum tempo para que a idéia de Nação brasileira competisse com a de Nação portuguesa; nestes anos movediços aqui estudados a Nação portuguesa era tanto percebida como a reunião de todos os súditos do soberano português, numa mentalidade política típica de Antigo Regime, como uma Nação formada por um conjunto de homens pactuados politicamente. Além disso, influiam os ritmos mais e menos acelerados dos conflitos regionais em cada formação social da América portuguesa, por todas as variações que comportavam, como vimos acima.

Em suma, não podemos lidar apenas com os extremos da curta duração dos acontecimentos políticos e da longa duração da mentalidade do Antigo Regime que a estes atribui inteligibilidade. Como bem mostram os resultados de pesquisa apresentados no Independência, não podemos cobrir a rapidez dos eventos políticos destes tempos de crise com o manto cultural do Antigo Regime que tudo explica e desacelera, tornando previsiveis para o historiador as ações e as idéias de todos os que viveram nos variados cantos do Império desde o início do tempo moderno, fossem "homens do comum"100, nobres, mercadores, gente de ofício e até mesmo escravos. Um dos êxitos dos autores deste livro é o cuidado para não naturalizar a cultura do Antigo Regime, não fazer dela um substrato tão anterior às demais circunstâncias históricas e tão duradouro no tempo que, ao cabo, extingue as transformações.

\section{Um novo patamar de discussão historiográfica sobre o fim do período colonial}

Por tudo que se viu aqui, pensamos ser apropriado recomendar vivamente a leitura do Independência: história e historiografia. A solidez do conjunto de artigos, bem como a variedade dos objetos e tratamentos dados à Independência, possibilitam que o leitor percorra o livro como fizemos: a sua maneira.

Depois de todos os textos lidos, sentimos falta de ver tratada a figura política de D.Pedro. Quais eram seus interesses? Como e com quem se articulava em torno do Rio de Janeiro? Como se comunicava e como era tratado pelas autoridades das demais províncias? Muito do que já se estudou sobre este Príncipe e Imperador poderia fazer parte das reflexões destes historiadores. Do mesmo modo, ficou ausente do livro a face religiosa da cultura política que foi por eles tão bem esquadrinhada. Lúcia Pereira das Neves reconhece a relevância da religiosidade para o entendimento da mentalidade política de então; encontrou escritos em que o Príncipe Pedro era comparado a Jesus Cristo e D.João ao Pai Supremo, em que D.Pedro se tornava pacificador porque ganhara o espírito do Rei Davi. ${ }^{101}$

0 ponto em que chegaram as pesquisas até o momento - não nos referimos apenas àquelas presentes neste livro - faz com que lamentemos a indefinição dos contornos de cada um dos grupos sociais envolvidos na crise do Antigo Regime e na formação do Estado brasileiro. 


\section{2}

István Jancsó. "Independência, independências" In: István Jancsó (org.). Independência, op. Cit., p. 28-ss.

103

Wilma Peres Costa."A Independência na historiografia brasileira" In: István Jancsó (org.). Independência, op. Cit., p. 53-118.

\section{4}

IImar Rohloff de Mattos."Construtores e herdeiros. A trama dos interesses na construção da unidade política" In: István Jancsó (org.). Independência, op. Cit., p. 271-300.

\section{5}

István Jancsó e João Paulo Pimenta."Peças de um mosaico (ou apontamentos para o estudo da emergência da identidade nacional brasileira)" In: Carlos Guilherme Mota (org.). Viagem incompleta. A experiência brasileira (15002000). São Paulo: Senac, 2000, p. 127-175.

\section{6}

IImar Rohloff de Mattos."Construtores e herdeiros. A trama dos interesses na construção da unidade política" In: István Jancsó (org.). Independência, op. Cit., p. 271-300.

\section{7}

István Jancsó. "Independência, independências" In: István Jancsó (org.). Independência, op. Cit., p. 17-48.
Como mostraram os que estudam a história da escravidão, os cativos e por extensão os forros eram uma população muito diversificada quanto aos estilos de vida, às visões de mundo e, conseqüentemente, quanto ao que entendiam por liberdade e como lutavam por ela. É preciso conhecer com mais acuidade a arraia miúda, os "homens do comum", como se dizia à época, bem como aqueles que vimos chamando de "elites", que estavam na ponta superior da sociedade colonial. No texto em que abre o livro, professor István Jancsó adverte quanto à inadequação do uso do termo "elites"; lembra que era a nobreza o estrato superior nas sociedades de Antigo Regime e que a "posição de cada qual na hierarquia social se dava, à época, com base num mix de patrimônios tangiveis e intangiveis"102; portanto, é necessário caracterizar com mais precisão as muitas frações de "elite".

Neste livro, há três textos que nasceram clássicos: esse de István Jancsó, o "A Independência na historiografia brasileira", da professora Wilma Peres Costa, ${ }^{103}$ da Unicamp, e o "Construtores e herdeiros. A trama dos interesses na construção da unidade política", de Ilmar Rohloff de Mattos, ${ }^{104}$ da PUC do Rio de Janeiro, anteriormente publicado nesta revista virtual. Em vista da densidade das páginas que tais autores apresentam, este artigo arrisca parecer um tanto trivial.

Wilma Peres Costa optou pelas "continuidades" e "descontinuidades" como "fio condutor" na análise da produção historiográfica brasileira sobre a Independência, desde Varnhagen até a tese de doutoramento de João Paulo Garrido Pimenta, 0 Brasil e a América Espanhola (1808-1822), defendida em 2003, na USP. Pela abordagem, logo vemos que se consagra também aos desdobramentos da Independência na formação do Estado e da Nação no Brasil. Entre a produção recente, professora Wilma destaca o "Peças de um mosaico..."105, e aponta que hoje os pesquisadores estão mais livres das dicotomias dos anos de 1970, isto é, que entendem como problemas de pesquisa as relações entre política e economia e, do mesmo modo, entre o que mudou e o que permaneceu igual após a separação de Portugal. A profundidade com que analisa a historiografia da Independência deixa o leitor querendo mais e mais páginas de texto.

Quanto ao "Construtores e herdeiros...", 106 de autoria do professor IImar Mattos, busca entender a denominação Império do Brasil atribuída em 1822, as mudanças de significado que este "Império" alcançou na sua primeira década de existência e o modo como, ao longo dessas mudanças, foi sendo associado ao Estado imperial e à Nação brasileira, num "expansionismo para dentro". Prescindimos de tratar o texto neste artigo e nos restringimos a aconselhar sua leitura, imperiosa e alentadora. Lembramos ainda que foi comentado no primeiro número desta mesma Revista Almanack Braziliense por Cecilia Helena Salles de Oliveira e por Wilma Peres Costa.

Na segunda metade do século passado, a maioria dos estudos sobre a Independência viam notadamente as oposições entre a colônia e a metrópole; de uma década para cá, passaram a ver apenas um imenso império lusitano, onde todos os homens se inseriam nos quadros culturais e políticos do mesmo Antigo Regime. Com o texto "Independência, independências" do professor István Jancsó, ${ }^{107}$ consolida-se uma interpretação da sociedade colonial e do rompimento com Portugal que, aqui e ali, pipocava nos últimos anos em vislumbres esparsos nas páginas dos historiadores, como no "O Império em apuros. Notas para o estudo das 'alterações' ultramarinas e das práticas políticas no Império colonial português, séculos XVII 
108

Luciano Figueiredo."0 Império em apuros. Notas para o estudo das 'alterações' ultramarinas e das práticas políticas no Império colonial português, séculos XVII e XVIII" In: FURTADO, Júnia Ferreira. Diálogos oceânicos. Minas Gerais e as novas abordagens para uma história do Império Ultramarino Português. Belo Horizonte: UFMG, 2001, p.254.

109

István Jancsó. "Independência, independências" In: István Jancsó (org.). Independência, op. Cit., p. 22. e XVIII", de Luciano Figueiredo. Comparando as revoltas ocorridas no século $\mathrm{XVII}$ nos vários cantos do Império com aquelas que se deram no XVIII, este historiador do Rio de Janeiro indica no final do texto:

"Se, enquanto periferia, [a América portuguesa] reitera os padrões da cultura política reinol, foi tão-somente como uma colônia mercantilista que transformou práticas e discursos políticos na paisagem americana e, de modo reflexo, em Portugal."108 (grifos do autor)

Nas palavras de István Jancsó esta ambivalência aparece mais desenvolvida, pensada para as questões identitárias da América portuguesa e para um jogo sutil entre o geral e o particular, entre tensão e acomodação ao longo do tempo:

"O fato de a matriz das formações sociais luso-americanas radicarse na lógica do ancien régime português faz com que as especificidades americanas devam ser tomadas como problema crucial a ser enfrentado. Por um lado, porque aquelas sociedades reciclaram os paradigmas peninsulares por força da sua condição colonial e escravista e, por outro, porque a longa história da interface entre a metrópole européia e suas colônias americanas não foi linear." 109 (grifos nossos)

Como anunciamos no início, cremos que os textos do Independência: história e historiografia mostram que estão em bom patamar as discussões acerca do final do período colonial. Pensamos que isso é possível porque suas abordagens contemplam dois eixos: de um lado, a busca da alteridade e da peculiaridade de idéias e atuações políticas, apreendendo-as como experiências, e de outro, a tentativa de captar os arranjos entre permanências e transformações nas múltiplas temporalidades do Império português em crise. 